\title{
correspondence
}

\section{The Piltdown hoax: cui bono?}

SIR,-By far the most sensational feature of the Piltdown hoax, that has remained hidden from the public gaze for so long, is that it was planned and executed by eminent scientists against one of their own number.

Until recently there have been two main hypotheses regarding the identity of the perpetrator of the Piltdown hoax. That espoused by Weiner (The Piltdown Hoax, Oxford University Press, 1955), inferring the guilt of the amateur Dawson, is far the more acceptable as it absolves the academic world from any involvement. The other view is that Dawson was the scapegoat, and the hoax was part of a conspiracy on the part of scientists to delude the public into accepting the anti-religious idea of human evolution (M. Bowden, A pe-men fact or fallacy? Sovereign Publications, 1977). This thesis, of which there are hints in Langham's letter (18 January, page 170), even suggests that Smith Woodward "may have been a willing accomplice". Hence, Elliott

Smith, who nailed his banner firmly to the Piltdown mast, could be imagined to have been the instigator.

Douglas (2 November, page 11) has provided a signal service by making us look afresh at the evidence and consider a "grudge against one of the principals" as a fruitful line of enquiry. The incident of the Sherborne horse's head, if nothing else, was a successful and deliberate demonstration by Sollas of Woodward's incompetence. In this context, it is indeed difficult to imagine Dawson being party to any conspiracy aimed at belittling his close friend of many years standing (from 1884 until his death in 1916). He may possibly have been persuaded to help "encourage the evidence", and it is difficult to avoid postulating some kind of direct involvement. The way in which the desperately wished for lower jaw was flicked up by Dawson's pick, so that it landed literally at Smith Woodward's feet, has such an air of theatre about it that one is bound to be suspicious of such a startling coincidence. When the search was on for the missing canine, Teilhard de Chardin sat down to rest on a heap of gravel that Dawson and Woodward had already sifted. They actually told him that there was no point in searching there, but within a few minutes of casual probing with his fingers the canine appeared, yet another startling coincidence. (This event might well place Teilhard de Chardin among the suspects). The subsequent sudden appearance of the "cricket bat", from the soil under the hedge where they usually lunched, was surely stretching credulity to breaking point. Everything that Smith Woodward wanted, turned up and, moreover, in the order in which he wanted it.

Every good hoax, to be effective, needs to carry certain hallmarks that allow it to be recognised as such by all and sundry, with the main exception of the victim for whom it was designed. Let us now look, not at Woodward's friends, but at his enemies. Douglas has already drawn our attention to the strong possibility of Sollas being involved. Sollas was Britain's leading expert on fossil man, who had just given his Presidential Address to the Geological Society on fossil man and had recently published Ancient Hunters (1911). Here was a man who had pioneered over many years the technique of serial sectioning, which enabled palaeontologists to examine the internal structures of fossils that otherwise would never have been accessible for study, a technique which Smith Woodward contemptuously dismissed as a "mere toy". And here was Smith Woodward with pretensions, but no expertise, announcing his ambition to discover the earliest man, and moreover, in Britain. Was this not as close to an invitation as one could imagine?

Weiner (4 January, page 10) draws attention to Oakley's letter to The Times (7 November 1978) regarding Sollas's possible use of potassium bichromate, but he seems to have missed my reply (The Times, 25 November) refuting Oakley. My letter also mentioned that Dr M. A. C. Hinton was the likely source of the medieval orang utan lower jaw and that Hinton had stated that the hoax was initially planned and executed within the Natural History Museum.

Unfortunately the short paragraph referring to Hinton's possible involvement was edited out of my original article in Nature (2 November, pages 11-13)

In the spring of 1912 Dawson brought the five Piltdown skull fragments to Smith Woodward, but to be certain of its import, it was vital to find the lower jaw. In 1910 Hinton was given the status of a Voluntary Worker in Smith Woodward's Department of Geologv to work on fossil rodents. He managed somehow to offend Smith Woodward to such an extent that in 1912 he transferred to the Department of Zoology to continue his work there (eventually in 1936 becoming Keeper of Zoology and retiring in 1945). The available evidence suggests that the medieval orang utan lower jaw came from a box of unregistered material from the Everett Collection to which Hinton then had access. Hinton (The Times, 4 December 1953) stressed that the zoologists in the museum would have unhesitatingly referred the lower jaw and canine to a chimpanzee had the material come within the orbit of the Zoology Department! He claimed that in their eyes G. S. Miller's analysis settled the matter and relieved them of the necessity of expressing any opinion and thus arousing hostility within the museum. In retrospect, this epistle from Hinton takes on a new significance.

From the people that knew Hinton well, it is accepted that he must have been involved in the promulgation of the hoax and it is even claimed that he "virtually confessed" to this, prior to his death. Nevertheless, there was always the nagging suspicion that there was a more knowledgeable figure in the background; Douglas's suggestion at last provides the clue to his identity.

Douglas asks "Did they [the people who exposed the fraud] ever try to find out if Smith Woodward had any particular enemies who might do such a thing? No. They did not". If a crime is committed against an individual, the first task, having ascertained that the deed has in fact been committed, is to determine if anyone had a strong motive. Such an approach would have pointed in the direction of the Natural History Museum and Oxford. Without wishing to be uncharitable, perhaps this is the reason the grudge theory was never followed up. This would explain the cameo of Sir Gavin de Beer "rolling on his settee, wringing his hands and crying 'What can $I$ do? What can I do?" "as the evidence on Piltdown unfolded. It is not a scandal for an institution to have been duped by a hoax, but if it transpires that it has been initiated in the same institution, it certainly is.

Finally Weiner's accusation of Douglas besmirching Sollas's reputation cannot be left unanswered. Given the circumstances in the 1910-1912 period, given the personality of Smith

Woodward. I wonder how many people would have resisted the temptation "to present somebody, who is claiming to be an expert in a field, with something everybody would know is so ludicrous that he would make an utter fool of himself and be shot down in flames". The conspirators misjudged the perspicacity of their colleagues, although Waterston, Lankester, Boule, Miller and Weidenreich doubted the association of ape jaw and human skull from the very beginning. Above all, however, Piltdown engendered such an enthusiastic nationalistic fervour, that the critical faculties of the scientific community seem to have been overwhelmed. and this surely was the tragedy of Piltdown.

Yours faithfully,

L. B. HalsteAD

Department of Geology,

University of Reading, $U \boldsymbol{K}$.

\section{False- or pseudogalena}

SIR.--Joe Schwartz (25 January, page 255 ) has confused galena with false-galena or pseudogalena (sphalerite). Yours faithfully J. C. Kauer

Du Pont. Wilmington,

Delaware, USA 